\author{
Renata Nurzyńska-Wierdak, AndRZEJ SAŁata, RAFAŁ Stepaniuk
}

Katedra Warzywnictwa i Roślin Leczniczych

Uniwersytet Przyrodniczy $w$ Lublinie

Leszczyńskiego 58; 20-068 Lublin

E-mail: renata.nurzynska@up.lublin.pl

\title{
PROZDROWOTNE WŁAŚCIWOŚCI KARCZOCHA ZWYCZAJNEGO (CYNARA SCOLYMUS L., ASTERACEAE)
}

\section{WSTEP}

Warzywa należą do podstawowych składników pożywienia człowieka, a ich spożycie zapewnia dobre samopoczucie, zdrowie, sprawność fizyczną i umysłową. W ostatnim czasie coraz częściej zauważa się, że w Polsce spożycie warzyw, owoców i ich przetworów nie jest wystarczające (STROJEWSKA 2013). MURAWSKA (2016) podaje, że konsumpcja warzyw w polskich gospodarstwach domowych zmniejsza się, a przy malejacym spożyciu świeżych warzyw wzrasta konsumpcja przetworów warzywnych. Tymczasem to właśnie świeże warzywa powinny dominować w diecie nad produktami przetworzonymi, cechującymi się $z$ reguły mniejsza wartościa odżywczą. Tym bardziej, że w Polsce świeże warzywa m.in. $z$ grupy warzyw kapustnych, korzeniowych czy cebulowych, w wieksszości dostępne sa przez cały rok (ze zbioru i przechowywania). Warzywa dostarczaja organizmowi nie tylko związków mineralnych i witamin, ale także białka, skrobi, błonnika, flawonoidów i innych substancji biologicznie aktywnych. Dieta podstawowa powinna być zbilansowana pod względem energetycznym i odżywczym. Niewłaściwa dieta i popełniane błędy żywieniowe prowadza do występowania szeregu chorób dietozależnych: otyłości, miażdżycy, chorób nowotworowych układu pokarmowego czy cukrzycy typu 2 (PYRZYŃSKA 2014). Zgodnie $z$ definicjami i zaleceniami żywieniowymi, wartość energetyczna pożywienia jest istotnym elementem jego wartości odżywczej. Jednocześnie wartość energetyczna produktów spożywczych determinowana jest przede wszystkim zawartościa wody i tłuszczów (GAWECKI i HRYNIEWIECKI 2000), a źle zbilansowana dieta o podwyższonym udziale produktów bardzo wysokoenergetycznych przyczynia się do wielu groźnych schorzeń metabolicznych, układu krążenia, a także chorób nowotworowych. Badania HARTON i współaut. (2015) dowodza, że spożycie warzyw u dzieci przedszkolnych zmniejsza się wraz $z$ wiekiem, a blisko 90\% $z$ nich nie realizuje zaleceń dziennego spożycia warzyw. Autorzy wskazuja ponadto, że spożycie warzyw przez dzieci w głównej mierze wynika $z$ realizacji zaleceń w spożyciu warzyw przez rodziców. Zauważono także, że warzywa sa szczególnie cennym składnikiem diety osób starszych powyżej 65-70 roku życia, gdyż pozytywnie wpływaja na funkcje poznawcze, co przypisuje się głównie obecności karotenoidów i flawonoidów (ZIELIŃSKA i współaut. 2017).

Krajowa produkcja warzyw stanowi 6,5\% ogólnej produkcji rolniczej i jest znaczaca pozycją w produkcji ogrodniczej (FosiŃSKA i współaut. 2015). W porównaniu $z$ poprzednimi latami, obecnie obserwowany jest wzrost produkcji warzyw oraz rozszerzenie asortymentu uprawianych gatunków. Różnorodność warzyw pod względem kształtu, barwy, walorów smakowych, dietetycznych i leczniczych ułatwia komponowanie codziennych posiłków, a także podnosi ich wartość odżywcza. Jednym $z$ mniej znanych w Polsce gatunków warzyw o cennych walorach prozdrowotnych jest karczoch zwyczajny. Zainteresowanie karczochem wśród konsumentów i producentów zwiększa się, na co wpływ maja jego walory dietetyczne i fitoterapeutyczne. W ostatnich latach rosnace 
zapotrzebowanie na żywność funkcjonalną przyniosło duże zainteresowanie naturalnymi zwiazkami o właściwościach przeciwutleniających. CECCARELLI i współaut. (2010) podaja, że zawartość przeciwutleniaczy jest ważnym parametrem jakości warzyw i kluczowym czynnikiem rozwoju rynku, a pozyskiwanie i rozpowszechnianie informacji naukowych na temat wartości odżywczej i prozdrowotnej karczocha może wpływać na wybory konsumenckie.

\section{POCHODZENIE, BIOLOGIA I WALORY PROZDROWOTNE KARCZOCHA}

Karczoch zwyczajny (Cynara scolymus L.) $z$ rodziny Asteraceae, pochodzi prawdopodobnie $z$ terenów dzisiejszej Etiopii (FOURY 2005). Znany w uprawie już od czasów starożytnych (PORTIS i współaut. 2005), w XVII w. uprawiany był także w Polsce (HoJDEN 1999). Obecnie karczoch uprawiany jest jako roślina warzywna $\mathrm{w}$ wielu krajach śródziemnomorskich i w Ameryce Północnej oraz jako roślina lecznicza, głównie w Niemczech i Polsce (KoŁODZIEJ 2010). W cieplejszym klimacie karczoch jest bylina, a w warunkach klimatu umiarkowanego - roślina jednoroczna (wymarza $\mathrm{w}$ temperaturze poniżej $-10^{\circ} \mathrm{C}$ ). Roślina dorasta do $2 \mathrm{~m}$ wysokości. Początkowo wytwarza dużą rozetę liściową osiagajaca do $90 \mathrm{~cm}$ długości, złożona z długoogonkowych, głęboko wcinanych, klapowatych, pierzastodzielnych, od spodu kutnerowato owłosionych liści. Kutner pokrywajacy liście nadaje im charakterystyczna srebrzysta barwę (MORISON i współaut. 2000). Przechodzac w fazę generatywną, karczoch wykształca gruba, rozgałęzioną łodygę, zakończona koszyczkami kwiatostanowymi o fioletowo-czerwonych kwiatach. Niedojrzałe koszyczki karczocha maja barwę zielona $z$ turkusowym lub czerwonym przebarwieniem, co jest cecha odmianowa, i sa okryte zmięśniałymi łuskami (IERNA i współaut. 2004). Karczoch jest roślina obcopylna, owadopylna, zapylana głównie przez pszczołę miodna wabioną dużym, barwnym okwiatem, obfitościa nektaru i silnym aromatem (MORISON i współaut. 2000). W Polsce rośliny karczocha kwitna od lipca do października (SAŁATA 2005). Owocem karczocha jest szarobrazowa niełupka, zachowująca zdolność kiełkowania przez 4-6 lat (KoŁOTA 2000, KoŁODZIEJ 2010). Częścia jadalna jest tzw. „serce karczocha", mięsiste dno nierozwiniętego kwiatostanu oraz zmięśniałe nasady listków okrywy koszyczka. Serca karczochów zawieraja białko (2-3\%), węglowodany (7-15\%), tłuszcz $(0,1 \%)$, witaminy: C $(10 \mathrm{mg} / 100$ g.św.m. $)$, $\mathrm{B}_{1}\left(0,14 \mathrm{mg} / 100\right.$ g.św.m.), $\mathrm{B}_{2}(0,01 \mathrm{mg} / 100$ g.św.m.), $\quad B_{6} \quad(0,9 \mathrm{mg} / 100 \quad$ g.św.m.), A (4 $\mu \mathrm{g} / 100$ g.św.m.), E (0,2 mg/100 g.św.m.), zwiąki mineralne potasu $(350 \mathrm{mg} / 100$ g.św.m.), sodu (47 mg/100 g.św.m.), fosforu (130 mg/100 g.św.m.), wapnia (53 mg/100 g.św.m.), magnezu (26 mg/100 g.św.m.) i żelaza (1,5 mg/100 g.św.m.). Sa cenione ze względu na walory dietetyczne i smakowe, polecane m.in. w dietach cukrzycowych (Ko€OTA 2000, CeCCARELli i współaut. 2010, KoŁODZIEJ 2010). Niewielka zawartość białka, bardzo mała zawartość tłuszczu oraz obecność oksydaz i inuliny sprawiaja, że karczoch polecany jest diabetykom. Warzywo to jest tradycyjnym składnikiem diety śródziemnomorskiej (CECCARELLI i współaut. 2010). Karczochy można spożywać na surowo $\mathrm{w}$ postaci sałatek lub $\mathrm{z}$ dodatkiem sosów, gotować, dusić w oliwie, piec, smażyć, grillować, faszerować, a także konserwować i zamrażać. Jadalne są również bielone ogonki liściowe karczocha, a $z$ jego nasion otrzymywany jest olej. FOTI i współaut. (1999) podaja, że nasiona karczocha zawieraja $21,6 \%$ białka, $17,1 \%$ włókna, $24,05 \%$ oleju i 3,8\% popiołu.

Karczoch, podobnie jak inne niskoenergetyczne warzywa, korzystnie wpływa na zrównoważony bilans między energią przyjmowana $z$ pożywieniem i wykorzystywana przez ustrój. $100 \mathrm{~g}$ jadalnych części karczocha dostarcza organizmowi jedynie 10 kalorii (BURDZENIA 2014), powiększając jednocześnie pulę wolnych aminokwasów, białka, węglowodanów, witamin i składników mineralnych. Karczoch jest jednym $z$ najbogatszych dietetycznych źródeł polifenoli o wysokiej biodostępności; zawiera również inulinę, błonnik, witaminy i składniki mineralne. Inulina (Ryc. 1) jest roślinnym węglowodanem, który w ostatnim czasie staje się przedmiotem zainteresowania licznych programów badań nad żywnością. Jest prebiotykiem należącym do frakcji rozpuszczalnego błonnika pokarmowego, o niskiej wartości energetycznej. Inulina wpływa na metabolizm lipidów, działa bifidogennie (stymuluje

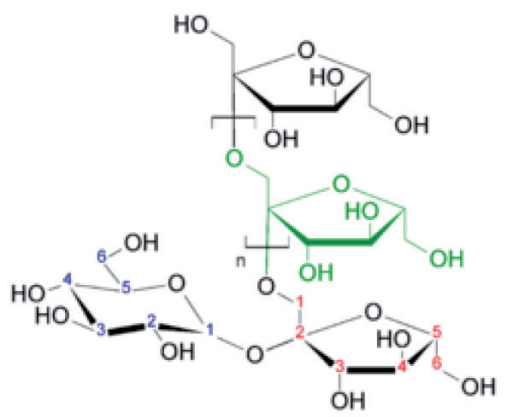

Ryc. 1 Inulina - związek $z$ grupy węglowodanów gromadzony $\mathrm{w}$ większej ilości przez rośliny $\mathrm{z}$ rodziny Alliaceae i Asteraceae. 
wzrost odpowiednich bakterii), zmniejsza ryzyko schorzeń układu pokarmowego, wpływa na normalizację stężenia glukozy we krwi oraz zmniejsza poziom cholesterolu i lipidów w surowicy, zwiększa absorpcję wapnia, magnezu i żelaza w przewodzie pokarmowym, reguluje przyswajanie składników pokarmowych, wzmacnia apetyt, stymuluje układ odpornościowy (LÓPEZ-MOLINA i współaut. 2005, SHOAIB i współaut. 2016). LLORACH i współaut. (2002) sugeruja zastosowanie ekstraktów $z$ karczocha w produkcji żywności funkcjonalnej, głównie w celu zmniejszenia utleniania lipidów i zwiększenia właściwości prozdrowotnych produktów. Wyniki badań LóPEZ-MOLINA i współaut. (2005) wskazuja na duże możliwości zastosowania inuliny karczocha w produkcji żywności. Szczególnie cenne jest jej działanie prebiotyczne wykazane jako długotrwały efekt bifidogenny na Bifidobacterium bifidum.

Wyciagi $z$ karczocha sa cenne także dla przemysłu spożywczego. Właściwości przeciwdrobnoustrojowe stwarzają możliwości zastosowania ich jako środków konserwujących żywność (ZHU i współaut. 2004). Wyciagi $z$ kwiatów karczocha badane sa także jako potencjalne źródło naturalnych enzymów, mogacych mieć zastosowanie w produkcji sera (CostaBILE i współaut. 2010).

\section{SKŁADNIKI BIOAKTYWNE KARCZOCHA}

Surowcem zielarskim karczocha sa świeże lub wysuszone liście (Cynarae folium), zebrane przed rozwojem kwiatów. Wśród licznych związków biologicznie aktywnych karczocha wyróżnia się 4 najważniejsze grupy: kwasy fenolowe (kwas chlorogenowy, kwas kawowy, kwas 1,5-dikawoilochinowy zwany cynaryna), flawonoidy (skolimozyd, cynarozyd, luteolina), gorzkie laktony seskwiterpenowe (cynaropikryna, dehydrocynaropikryna, cynaratriol, grosheimina) oraz garbniki (PANDINO i współaut. 2011) (Ryc. 2). Kwasy fenolowe $\mathrm{i}$ ich estry stanowia od 0,02 do $2 \%$ suchej masy liści i ziela karczocha (KuLzA i współaut. 2012), a udział flawonoidów w suchej masie ziela karczocha wynosi od 0,1 do 1,0\% (EICH i współaut. 2005, FRATIANNI i współaut. 2007). Laktony seskwiterpenowe i garbniki stanowia odpowiednio: powyżej $4 \%$ i $0,5-4,5 \%$ św.m. ziela karczocha (MoGLIA i współaut. 2008, HONERMEIER i współaut. 2009). W grupie kwasów fenolowych karczocha, zwanych polifenolokwasami lub kwasami kawoilochinowymi, dominuje kwas kawowy i kwas chinowy, tworzace liczne połączenia estrowe (SAŁATA i GRUSZECKI 2010; NEGRO i współaut. 2011, 2012). Wśród wymienionych zwiazków rozpoznano dotychczas 11 pochodnych kwasów kawoilochinowych,
A

B
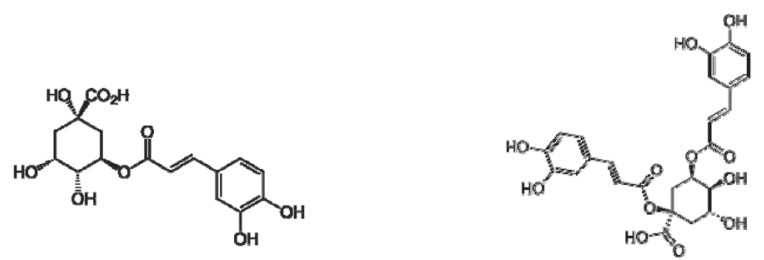

Ryc. 2 Kwas chlorogenowy (A) oraz cynaryna (B) - dwa główne składniki bioaktywne karczocha.

różniących się liczbą i umiejscowieniem grup hydroksylowych w czasteczce oraz stopniem ich zestryfikowania (LOMBARDO i współaut. 2010, PANDINO i współaut. 2011).

Skład chemiczny liści karczocha jest bardzo zróżnicowany i zależny od szeregu czynników: genetycznych (odmiana), ontogenetycznych (faza rozwoju) i środowiskowych (klimat, gleba). DI VENERE i współaut. (2005) poddali analizie liście 10 odmian karczocha, otrzymujac szeroki zakres zawartości kwasów fenolowych: 200-500 mg kwasu chlorogenowego i 300-600 mg kwasu dikawoilochinowego w $100 \mathrm{~g}$ św. masy. CURADI i współaut. (2005) prowadzili badania dotyczące rozmieszczenia związków polifenolowych w różnych organach karczocha. Okazało się, że w okresie wykształcania pędów kwiatostanowych zawartość kwasu chlorogenowego zmniejsza się z 3,9 do 2,4 mg/g.św.m., a następnie, wraz $z$ dalszym rozwojem, zwiększa do $2,98 \mathrm{~m} / \mathrm{g} \cdot \mathrm{s} w$. m. LOMBARDO i współaut. (2010) wyjaśnili, że synteza związków fenolowych zwiazana jest $z$ intensywna przemiana materii i odbywa się głównie w młodych organach rośliny, skąd związki te moga być przemieszczane do innych jej części. FRATIANNI i współaut. (2007) sugerują, że przemieszczanie się związków polifenolowych w roślinie karczocha jest forma jego adaptacji do zmieniajacych się warunków środowiska. Autorzy wykazali, że natężenie światła słonecznego ma bezpośredni wpływ na zawartość flawonoidów w liściach i kwiatostanach karczocha. Karczoch jest roślina klimatu ciepłego i o akumulacji polifenolokwasów w zielu decyduje także przebieg temperatury w danym roku. SALATA i BuCZKOWSKA (2007a) otrzymali 0,6075\% polifenolokwasów w zielu karczocha w 2004 r. oraz 0,4875\% tych związków w surowcu pozyskanym w 2005 r.

Analiza surowca kilkunastu odmian karczocha uprawianego we Włoszech wykazała, że zawartość flawonoidów mieści się w szerokim zakresie, od 0,53 do $2,39 \%$, a zawartość kwasów fenolowych ogółem wynosi 1,21,4\% (HAMMONDA i współaut. 1991). Badania przeprowadzone w Niemczech (MATTHES i HONERMEIER 2007) wskazuja, że rośliny od- 
miany White Giant gromadzą więcej kwasów fenolowych w zielu, niż rośliny odmiany Greek Globe (odpowiednio: 5,7 i 4,9\%). Według WANGA i współaut. (2003), liście karczocha odmian Imperial Star i Green Globe zawieraja więcej fenoli ogółem i cynaryny oraz maja wyższa aktywność antyoksydacyjna, niż liście odmiany Violet. CoINU i współaut. (2007) dowiedli, że liście karczocha i listki okrywowe kwiatostanu zawieraja te same kwasy fenolowe, a różnia się przede wszystkim profilem flaownoidów. Autorzy ocenili, że zarówno liście, jak i listki okrywowe zawieraja głównie: kwas 1,5-O-dikawoilochinowy, kwas chlorogenowy oraz glikozydy luteoliny (liście) i 7-O-glukuronid apigeniny (listki okrywowe), który nie występował w liściach. W liściach i kwiatostanach karczocha w największej ilości występuje kwas chlorogenowy (kwas 5-O-dikawoilochinowy) i cynaryna (kwas 1,3-O-dikawoilochinowy) (LATTANZio i współaut. 2009, PARUS 2013). Kwas chlorogenowy, zwiazek o silnej aktywności przeciwutleniającej, ma duże znaczenie w chemioprewencji chorób nowotworowych. Działa on również ochronnie na komórki watroby, przeciwzapalnie, żółciopędnie, a także hamuje przemiany kwasu $\gamma$-aminomasłowego (GABA) w ośrodkowym układzie nerwowym (MARINOVA i współaut. 2009, SATO i współaut. 2011, PARUS 2013).

Badania SAEATY i GRUSZECKIEGO (2010) wskazuja, że zawartość kwasów fenolowych zmniejsza się wraz $z$ wiekiem roślin karczocha. Najwięcej kwasów fenolowych ogółem rośliny gromadza $\mathrm{w}$ fazie wzrostu wegetatywnego $\mathrm{w}$ liściach $(3,167 \%)$ oraz $\mathrm{w}$ fazie generatywnej w młodych nierozwiniętych pakach (3,730\%). Młode nierozwinięte paki karczocha zawieraja więcej kwasu chlorogenowego i cynaryny, niż paki rozwinięte. Najwięcej kwasu kawowego rośliny gromadzą w liściach w fazie wzrostu wegetatywnego, a kwasu ferulowego $\mathrm{w}$ pakach $\mathrm{w}$ fazie wzrostu generatywnego (SAEATA i GRUSZECKI 2010). Poziom substancji aktywnych karczocha może być modyfikowany czynnikami agrotechnicznymi, takimi jak metoda uprawy, termin zbioru czy nawadnianie (SAEATA 2007, WINIARSKA 2006, SAzATA i współaut. 2016). Na terenie Lubelszczyzny, w zielu karczocha uprawianego $z$ rozsady, zawartość kwasów fenolowych ogółem wynosi 0,43-0,61\%, flawonoidów $0,19-0,28 \%$, a garbników $6,91-8,59 \%$, podczas gdy $\mathrm{w}$ roślinach uprawianych $z$ siewu bezpośredniego zawartość kwasów fenolowych i flawonoidów wynosi odpowiednio: $1,0 \%$ i $0,31 \%$ (SAEATA 2007, SAEATA i BUCZKOWSKA 2007b, KO€ODZIEJ i WINIARSKA 2012). Badania SAŁATY i współaut. (2016) dowodza, że nawadnianie plantacji karczocha wpływa na zwiększenie plonu świeżych liści karczo- cha oraz przyczynia sie do zwiększenia zawartości garbników, obniżenia zawartości kwasów fenolowych ogółem, nie zmieniajac natomiast zawartości flawonoidów. Ponadto, surowiec zbierany we wrześniu odznacza się większą zawartościa kwasów fenolowych i mniejszą flawonoidów, $\mathrm{w}$ porównaniu $\mathrm{z}$ surowcem pozyskiwanym $\mathrm{w}$ październiku.

Kolejnym czynnikiem zmienności składu chemicznego i aktywności biologicznej karczocha sa metody otrzymywania ekstraktów i obróbka surowca. LLORACH i współaut. (2002) wykazali, że ekstrakty metanolowe $z$ karczocha zawieraja więcej zwiazków fenolowych, niż ekstrakty wodne. LUTZ i wspólaut. (2011) dowiedli natomiast, że całkowita zawartość zwiazków fenolowych w młodych i dojrzałych karczochach jest podobna i zwiększa się po gotowaniu. Młode karczochy odznaczały się najwyższa całkowita zawartościa fenoli, kwasu kawowego, kwasu chlorogenowego i cynaryny, a także największa zdolnością wychwytywania wolnych rodników, mierzona metoda DPPH badania zdolności antyoksydacyjnej. Autorzy sugeruja, że młode karczochy stanowia szczególnie interesujace źródło przeciwutleniających polifenoli, a ich jakość poprawia obróbka termiczna.

\section{WALORY FITOTERAPEUTYCZNE KARCZOCHA}

Właściwości lecznicze karczocha zostały odkryte w XIV w., ale rośliny na stałe pojawiły się $\mathrm{w}$ medycynie dopiero w XVIII w. (Kulza i współaut. 2012). Pierwszą wyizolowana substancja czynna karczocha (1934 r.) była cynaryna, czyli kwas 1,5-dikawoilochinowy, wystepujaca praktycznie wyłacznie w świeżych liściach (BURDZENIA 2014). Kolejno poznawano inne zwiazki aktywne karczocha o cennych działaniach leczniczych, jak kwas chlorogenowy, cynarozyd i luteolina. Badania nad składem chemicznym i aktywnościa biologiczna karczocha prowadzone sa nadal, dostarczajac nowych cennych informacji. NoLDIN i współaut. (2003) wykazali, że flawonoidy glikozydowe (cynarozyd i skolimidozyd) sa głównymi składnikami aktywnymi surowca karczocha wraz $\mathrm{z}$ cynaropikryna, laktonami seskwiterpenowymi i triterpenoidem lupeolem. Natomiast cynaryna została wykryta w bardzo małym stężeniu. Wyniki te należy tłumaczyć zmiennościa genetyczną i środowiskową, której podlega większość substancji aktywnych gromadzonych $\mathrm{w}$ organach roślinnych. Zmienność składu chemicznego ma $z$ kolei wpływ na właściwości biologiczne, a tym samym walory lecznicze i wykorzystanie surowców roślinnych.

Pierwsze badania kliniczne $z$ ekstraktami z liści karczocha były prowadzone już w 
latach 30. XX w. W Polsce pierwsze prace dotyczące przeciwmiażdżycowego działania wyciagu $z$ liści karczocha przeprowadzono w latach 60. i 70. XX w. (SAMOCHOWIEC 1962, WóJCICKI 1978). Badania nad działaniem i wykorzystaniem substancji aktywnych karczocha sa kontynuowane, przynoszac coraz ciekawsze wyniki. Aktywność ekstraktów $z$ karczocha, a zwłaszcza choleretyczna (pobudzanie wydzielanie żółci) i przeciwutleniajacca, zależy od ich składu chemicznego (SPERONI i współaut. 2003). Właściwości fitoterapeutyczne karczocha nie sa zwiazane $Z$ obecnościa tylko jednej grupy związków, ale różnych jego składników. Wskazuje się także możliwości synergistycznego działania różnych zwiazków bioaktywnych (CECCARELLI i współaut. 2010). Głównym aspektem aktywności biologicznej karczocha jest ochrona i regeneracja komórek watroby. Polifenole karczocha działaja żółciotwórczo i żółciopędnie, jak również obniżają poziom glukozy oraz cholesterolu i triglicerydów w surowicy krwi (CECCARELli i współaut. 2010, AMMAL i SAAD 2012, MAGIED i współaut. 2016). Efekty stosowania świeżych i suchych liści karczocha dowodzą ich właściwości żółciopędnych i hepatostymulujacych, hepatoprotekcyjnych, normalizujacych czynności watroby. Wysoka skuteczność preparatów $z$ karczocha wynika $z$ bezpośredniego ich wpływu na poprawę czynności wątroby i pęcherzyka żółciowego (HASIK i LuTOMSKI 2000). Według BUNDY i współaut. (2008), wyciąg $z$ liści karczocha redukuje stężenie cholesterolu w osoczu u zdrowych osób $z$ łagodna i umiarkowana hipercholesterolemią. W grupie ochotników, spożywanie $1280 \mathrm{mg}$ standaryzowanego ekstraktu $z$ karczocha dziennie przez 12 dni spowodowało niewielka, ale korzystna różnice w poziomie cholesterolu całkowitego, $\mathrm{w}$ porównaniu $z$ grupa przyjmujaca placebo. Autorzy sugeruja, że pozornie pozytywny początkowy stan zdrowia badanej populacji mógł przyczynić się do obserwowanej niewielkiej odpowiedzi.

Przetwory $z$ karczocha zalecane sa w zaburzeniach żoładkowo-jelitowych. Wyciagi $z$ karczocha działaja pozytywnie na regulację przemiany materii, zmniejszaja symptomy podrażnienia żołądka, poprawiaja funkcjonowanie wątroby i dróg żółciowych, zwłaszcza przy obniżeniu zdolności do trawienia tłuszczów. Wynika to głównie $z$ jego właściwości przeciwwymiotnych, spazmolitycznych i wiatropędnych (KuLzA i współaut. 2012). Gorzkie laktony seskwiterpenowe karczocha reprezentowane przez cynaropikrynę (Ryc. 3), dehydrocynaropikrynę, cynaratriol oraz grosheiminę, określane sa mianem wzmacniajacych substancji gorzkich (Amarum tonicum) (EMENDÖRFER i współaut. 2005, KuLZA i

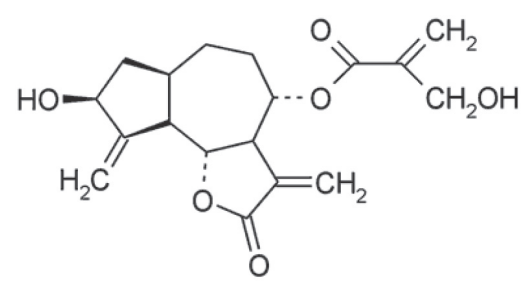

Ryc. 3. Cynaropikryna - najważniejszy z gorzkich laktonów seskwiterpenowych karczocha.

współaut. 2012). Wskazaniem do stosowania substancji goryczowych sa: brak łaknienia, dolegliwości żołąkowe na tle nerwicowym, dolegliwości dyspeptyczne, rekonwalescencja (HASIK i LUTOMSKI 2000). Cynaropikryna działa pobudzająco na wydzielanie żółci (KOHLMÜNZER 2007). Badania EMENDÖRFER i współaut. (2005) sugeruja, że cynaropikryna jest zwiazkiem odpowiedzialnym za działanie relaksacyjne na mięśnie gładkie, co przyczynia się do korzystnego wpływu na funkcjonowanie przewodu pokarmowego.

Wyciagi $z$ karczocha, dzięki obecności związków polifenolowych i innych zwiazków fitochemicznych, wykazują właściwości przeciwutleniajace i przeciwzapalne (COINU i współaut. 2007, SALEM i współaut. 2017). $Z$ badań ZAPOLSKIEJ-DOWNAR i współaut. (2002) wynika, że ekstrakt $z$ karczocha odznacza się właściwościami ochronnymi przed stresem oksydacyjnym wywołanym przez mediatory zapalne $i$ utlenione lipoproteidy niskiej gęstości (ox-LDL). Efekt ten można wykorzystać do leczenia miażdżycy tętnic i jej następstw. MAGIELSE i współaut. (2014) wykazali aktywność antyoksydacyjna wodnego wyciagu $z$ liści karczocha, zawierajacego $1,5 \%$ kwasów dikawoilochinowych, przy największym udziale kwasu chlorogenowego $(0,30 \%)$, oraz luteolinę $(0,15 \%)$, a aplikacja 0,2 g ekstraktu/kg masy ciała/dzień obniża stres oksydacyjny. Wyciag $z$ karczocha wykazuje dobra skuteczność hamowania in vitro utleniania LDL. JIMÉNEZ-ESCRIG i współaut. (2003) wykazali, że jeden gram suchej masy karczocha ma aktywność przeciwutleniajaca DPPH i FRAP wynoszaca odpowiednio: 29,2 i 62,6 mg witaminy C i 77,9 i $159 \mathrm{mg}$ witaminy E.

Zwiąki biologicznie aktywne karczocha, takie jak flawony lub kwasy hydroksycynamonowe, moga chronić białko przed utlenianiem zarówno w osoczu, jak i w erytrocytach. Podobne działanie ochronne wykazuje kwercetyna i epikatechina w osoczu, co stwierdzono $\mathrm{w}$ badaniach na modelu gryzoni (JIMÉNEZ-ESCRIG i współaut. 2003).

Karczoch jest roślina ceniona w medycynie tradycyjnej wielu krajów. W południowej Brazylii stosowany jest jako lek moczopędny, przeciwobrzękowy i obniżający gorączkę (DIC- 
KEL i współaut. 2007). Współczesne badania naukowe $\mathrm{w}$ dużej mierze potwierdzaja zasadność stosowania karczocha jako fitoterapeutyku. System opieki zdrowotnej w Brazylii, jeden $z$ największych publicznych systemów na świecie, odpowiedzialny za około $140 \mathrm{mi}-$ lionów obywateli (MENDES i współaut. 2008), zwraca uwage na rośliny lecznicze stosowane tradycyjnie. Do takich należy karczoch, wymieniany na liście gatunków roślin $z$ doniesieniami o wpływie na poziom glutationu zredukowanego (MAZZARI i PRIETO 2014) - związku organicznego, który odgrywa kluczowa rolę w utrzymaniu równowagi fizjologicznej między prooksydantami i antyoksydantami (BILSKA i współaut. 2007). Uzyskane przez FANTINI i współaut. (2011) wyniki badań laboratoryjnych sa pierwszym dowodem na działanie hipoglikemiczne preparatu $\mathrm{z}$ koszyczków karczocha i potwierdzają wcześniejsze obserwacje przeprowadzone u ludzi. Autorzy wykazali, że podanie znormalizowanego ekstraktu z koszyczków karczocha skutecznie zmniejsza gwałtowny wzrost glikemii po posiłku u dwóch różnych szczepów szczurów, w tym genetycznie otyłych. Flawonoidy karczocha także wzmacniaja i uszczelniaja naczynia krwionośne (GEBHARDT 1998). LI i współaut. (2004) potwierdzili skuteczne działanie leków z karczocha jako środków zapobiegających krwawieniom, a także chorobom układu krążenia. Autorzy ci wykazali, że wyciag z liści karczocha skutecznie ogranicza ryzyko wystapienia chorób sercowo-naczyniowych, gdyż zapobiega agregacji płytek krwi.

Aktywność biologiczna karczocha nie dotyczy jedynie wspomagania pracy wattroby i układu sercowo-naczyniowego. Rossoni i współaut. (2005) oraz PINELLi i współaut. (2007) podaja, że zwiąki polifenolowe karczocha chronia organizm przed nowotworami i stymuluja system immunologiczny. Według VELIOGLU i współaut. (1998), wśród polifenoli karczocha największa aktywność prewencyjna przeciwko nowotworom wykazuje kwas chlorogenowy, który silnie spowalnia działanie wielu enzymów uczestniczacych w podziale komórek nowotworowych. NOLDIN i współaut. (2003) dowiedli, że frakcja heksanowa ekstraktu $z$ karczocha wykazuje znaczną cytotoksyczność i dzialanie diuretyczne. ZHU i współaut. (2004) udokumentowali aktywność przeciwbakteryjną ekstraktów $z$ liści karczocha, wskazując że wszystkie związki fenolowe sa skuteczne wobec większości analizowanych szczepów, za najbardziej aktywne uznajac: kwas chlorogenowy, cynarynę, luteolin-7-O-rutynozyd $i$ cynarozyd. Podobnie ALGHAZEer i współaut. (2012) wykazali aktywność przeciwbakteryjną ekstraktów $z$ korzeni karczocha, w których oznaczyli obecność fenoli i flawono- idów. VAMANU i współaut. (2011) udowodnili aktywność antyoksydacyjna i przeciwbakteryjna ekstraktu $z$ liści karczocha sugerując, że działanie to uzasadnia tradycyjne zastosowanie karczocha w leczeniu niektórych chorób trawiennych, spowodowanych przez patogenne szczepy bakterii. Ekstrakty $z$ nadziemnych części karczocha działaja ponadto przeciwgrzybiczo, przy czym najbardziej aktywna jest frakcja etanolowa (ZHU i współaut. 2005). Dzięki swoim właściwościom antyoksydacyjnym, ekstrakt $z$ liści oraz paków kwiatostanowych karczocha jest także skutecznym środkiem przeciw zmianom spowodowanym promieniowaniem (AMMAL i SAAD 2012).

\section{PODSUMOWANIE}

Stan badań nad roślinami stosowanymi $\mathrm{w}$ medycynie tradycyjnej i ich rozwój podkreśla liczba prac naukowych poświęconych temu problemowi. Wiele $z$ nich poświęcono ekstraktom $z$ karczocha, badajac metody ich otrzymywania, analizujac ich skład chemiczny, aktywność biologiczna oraz możliwości wykorzystania w leczeniu różnych schorzeń. Wyniki tych badań jednoznacznie potwierdzaja cenne właściwości lecznicze karczocha i zasadność zastosowań fitoterapeutycznych. Główną grupa substancji aktywnych karczocha sa zwiazki polifenolowe, substancje wpływajace na większość procesów fizjologicznych. Jako najważniejsze działania lecznicze karczocha należy wymienić ochronę i wspomaganie funkcji watroby, przeciwdziałanie skutkom stresu oksydacyjnego i stanom zapalnym oraz wywołanym przez drobnoustroje chorobotwórcze. Oprócz tych ważnych działan fitoterapeutycznych, karczoch jest cennym źródłem prebiotyków, głównie inuliny, związków wprowadzanych do żywności w celu poprawy jej wartości odżywczej i prozdrowotnej. Dodajac do tego znaczne walory smakowe, otrzymujemy obraz żywności idealnej, odpowiadajacej słowom Hipokratesa: „Niech pożywienie będzie lekarstwem, a lekarstwo pożywieniem".

\section{Streszczenie}

Karczoch uprawiany jest jako roślina warzywna w wielu krajach śródziemnomorskich i w Ameryce Północnej, oraz jako roślina lecznicza, głównie w Niemczech i Polsce. Główna grupa substancji aktywnych karczocha sa zwiąki polifenolowe. Wyniki badań jednoznacznie potwierdzaja cenne właściwości lecznicze karczocha i zasadność zastosowań fitoterapeutycznych. Najważniejsze właściwości lecznicze karczocha to: ochrona i wsparcie funkcji wątroby, aktywność antyoksydacyjna oraz przeciwdrobnoustrojowa. Warzywo to jest również cennym źródłem prebiotyków, głównie inuliny i ma wszystkie zalety żywności funkcjonalnej. Karczoch może być zatem polecany nie tylko jako źródło związków leczniczych, ale 
także substancji wspomagających układ trawienny.

\section{LITERATURA}

Alghazeer R., El-Saltani H., Saleh N. A., Al-NAJJAR A., NAILI M. B., HEBAIl F., El-DEEB H., 2012. Antioxidant and antimicrobial activities of Cynara scolymus L. rhizomes. Mod. Appl. Sci. 6, 54-63.

AMmAL A. A., SAAD T. M., 2012. Effect of Cynara scolymus L. (Artichoke) extraction on hyperlipidemic induced by gamma radiation in male rats. Egypt. J. Hosp. Med. 47, 279- 290.

BILSKA A., KRYPCZYK A., WŁODEK L., 2007. Różne oblicza biologicznej roli glutationu. Postepy Hig. Med. Dosw. 61, 438-453.

Bundy R., Walker A. F., Middleton R. W., WalLIS C., SimpSON H. C. R., 2008. Artichoke leaf extract (Cynara scolymus) reduces plasma cholesterol in otherwise healthy hypercholesterolemic adults: A randomized, double blind placebo controlled trial. Phytomedicine 15, 668-675.

BURDZENIA O., 2014. Karczoch (Cynara scolymus) roślina lecznicza i przysmak. Fitoterapia 24, 57-63.

Ceccarelli N., Curadi M., Picciarelli P., MarTELlONI L., SBRANA C., GiovanNeTti M., 2010. Globe artichoke as a functional food. Mediterr. J. Nutr. Metab. 3, 197-201.

Coinu R., CARTa S., URgeghe P. P., Mulinacci N., Pinelli P., Franconi F., Romani A., 2007. Dose-effect study on the antioxidant properties of leaves and outer bracts of extracts obtained from Violetto di Toscana artichoke. Food Chem. 101, 524-531.

Costabile A., Kolida S., Klinder A., Gietl E., BAUERlein M., FrohberG C., LANDSChUTZE V., GIBSON G. R., 2010. A double-blind, placebo-controlled, cross-over study to establish the bifidogenic effect of a very-long-chain inulin extracted from globe artichoke (Cynara scolymus) in healthy human subjects. Br. J. Nutr., 104, 1007-1017.

Curadi M., CeCcarelli N., Picciarelli P., GrainFENBERG A., 2005. Quali-quantitative determination of chlorogenic acid in artichoke heads by mean of RP-HPLC and GC/MS. Acta Hort. 681, 511-515.

DiCKel M. L., RATES S. M., RitTeR M. R., 2007. Plants popularly used for loosing weight purposes in Porto Alegre, South Brazil. J. Ethnopharmacol. 109, 60-71.

Di Venere D., Linsalata B., Pace B., Bianco V. V., PERrino P., 2005. Polyphenol and inulin content in a collection of artichoke. Acta Hort. 681, 453-459.

EICH J., BAIER C., GRUN M., Wagenbreth D., ZiMMERMANN R., 2005. Artichoke leaves used for herbal drug production: Influences of nitrogen fertilization on yield and on pharmaceutical quality. Acta Hort. 681, 545-551.

EMENDÖRFER F., EMENDÖRFER F., BELLATO F., NOLDIN V.F., NIERO R., CECHINEL-FILHO V., 2005. Evaluation of the relaxant action of some Brazilian medicinal plants in isolated guinea-pig ileum and rat duodenum. J. Pharm. Pharmaceut. Sci. 8, 63-68.

Fantini N., Colombo G., Giori A., Riva A., MoraZZONI P., BOMBARDElli E., CARAI M. A. M., 2011. Evidence of glycemia-lowering effect by a Cynara scolymus L. extract in normal and obese rats. Phytother. Res. 25, 463-466.

Fosińska M., NOWICKI N A., CZART A., 2015. Analiza produkcji wybranych gatunków warzyw w Polsce oraz grupy producenckiej 'Daukus' $w$ latach 2011-2014. Infrastruktura i Ekologia Terenów Wiejskich 3, 691-699.

Foti S., MaURomicale G., Raccuia S. A., FAllico B., Fanella F., Maccarone E., 1999. Possible alternative utilization of Cynara spp. I. Biomass, grain yield and chemical composition of grain. Ind. Crops Prod. 10, 219-228.

FOURY C., 2005. Some historical sketches on artichoke and cardoon. Acta Hortic. 681, 29-38.

Fratianni F., TUCCI M., DE PALMA M., PEPE R., NAZZARO F., 2007. Polyphenolic composition in different parts of some cultivars of globe artichoke (Cynara cardunculus L. var. scolymus (L.) Fiori). Food Chem. 104, 1282-1286.

GAWECKI J., HRYNIEWIECKI L., 2000. Żywienie człowieka. Podstawy nauki o żywieniu. Wyd. Nauk. PWN, Warszawa.

GEBHARDT R., 1998. Inhibition of cholesterol biosynthesis in primary cultured rat hepatocytes by artichoke (Cynara scolymus L.) extracts. J. Pharm. Exp. Therap. 287, 1122-1128.

HAMMONDA F., EL-NESR M.S., ISMAIL S., 1991. HPLC evaluation of the active constituents in the newly introduced Romanian strain of $\mathrm{Cy}$ nara scolymus cultivated in Egypt. Planta Med. 57, 119-120.

HARTON A., FLORCZAK J., MYSZKOWSKA-RYCIAK J., GAJEWSKA D., 2015. Spożycie warzyw $i$ owoców przez dzieci $w$ wieku przedszkolnym. Prob. Hig. Epidemiol. 96, 732-736.

HASIK J., LUTOMSKI J., 2000. Ziołolecznictwo w chorobach wewnętrznych. Racjonalny poradnik dla lekarzy i farmaceutów. Borgis Wyd. Med., Warszawa.

HOJDEN B., 1999. Delikatny przysmak ukryty $w$ kolcach. Wiad. Zielar. 10, 11-12.

Honermeier B., Schaefer T., Goettmann S., 2009. Leaf yields and concentrations of chemical compounds of different cultivars of artichoke (Cynara cardunculus L.)- results from field experiments of the site Giessen. J. Med. Spice Plant. 14, 76-83.

Ierna A., Restuccia A., Mauromicale G., 2004. Effect of seed osmopriming on germination of Cynara cardunculus under low, optimal and high temperatures. Acta Hort. 660, 333-338.

JIMÉNEZ-ESCRIG A., DRAGSTED L.O., DANESHWAR B., Pulido R., Saura-Calixto F., 2003. In vitro antioxidant activities of edible artichoke (Cynara scolymus L.) and effect on biomarkers of antioxidants in rats. J. Agric. Food Chem. $51,5540-5545$

KoHLMÜNZER S., 2007. Farmakognozja. Wyd. Lek. PZWL, Warszawa.

KoŁODZIEJ B., 2010. Uprawa ziót. Poradnik dla plantatorów. PWRiL. Warszawa.

KOEODZIEJ B., WINIARSKA S., 2012. The effect of selected cultivation methods on yield and quality of artichoke (Cynara scolymus L.) raw material. Acta Sci. Pol. Hortorum Cultus. 11, 171-182.

KoŁota E., 2000. Karczoch [W:] Polowa uprawa warzyw. ORŁOWSKI M. (red.). Wyd. Brasika, Szczecin, 391-393.

KUlZA M., ADAMSKA K., SEŃCZUK-PRZYBYŁOWSKA M., WOŹNIAK A., WACHOWIAK A., MIECHOWICZ I., HoroszkiEwICZ M., NOWAK G., FlOREK E., 2012. Karczoch zwyczajny - lek roślinny. Przegląd Lekarski 69, 1122-1126.

LatTanziO V., KROON P.A., Linsalata V., CARdinaLI A., 2009. Globe artichoke: A functional food and source of nutraceutical ingredients. J. Func. Food. 1, 131-144.

Li H., XIA N., BRAUSCH I., YAO Y., ForstemanN U., 2004. Flavonoids from artichoke (Cynara 
scolymus L.) up-regulate endothelial-type nitric-oxide synthase gene expression in human endothelial cells. J. Pharmacol. Exp. Ther. 310, 926-932.

LLORACH R., ESPIN J.C., TOMAS-BARBERAN F.A., FERRERES F., 2002. Artichoke (Cynara scoly mus L.) byproducts as a potential source of health-promoting antioxidant phenolics. J. Agric. Food Chem. 50, 3458-3464.

LOMBARDO S., PANDINO G., MAUROMICALE G., KNÖDlER M., CARLE R., SCHIEBER A., 2010. Influence of genotype, harvest time and plant part on polyphenolic composition of globe ar tichoke /Cynara cardunculus L. var. scolymus (L.) Fiori]. Food Chem. 119, 1175-1181.

LÓPEZ-MOLINA D., NAVARRO-MARTínez M. D., ROJAS MElgarejo F., Hiner A. N. P., CHAZARRA S. RODRÍGUEZ-LÓPEZ J. N., 2005. Molecular properties and prebiotic effect of inulin obtained from artichoke (Cynara scolymus L.). Phytochemistry 66, 1476-1484.

Lutz M., Henríquez C., Escobar M., 2011. Chemical composition and antioxidant properties of mature and baby artichokes (Cynara scolymus L.), raw and cooked. J. Food Compos. Anal. $24,49-54$.

MAGied M. M. A., Hussien S. E. D., ZAKI S. M., EL SAID R. M., 2016. Artichoke (Cynara scolymus L.) leaves and heads extracts as hypoglycemic and hypocholesterolemic in rats. J. Food Nutr. Res. 4, 60-68.

Magielse J., Verlaet A., BReynaert A., KeEnoy B. M., Apers S., PIETERS L., Hermans N., 2014. Investigation of the in vivo antioxidative activity of Cynara scolymus (artichoke) leaf extract in the streptozotocin-induced diabetic rat Mol. Nutr. Food Res. 58, 211-215.

MARINOVA E. M., TONEVA A., YANISHLIEVA N., 2009. Comparison of the antioxidative properties of caffeic and chlorogenic acids. Food Chem. $114,1498-1502$.

MATTHES C., HONERMEIER B., 2007. Cultivation of the artichoke as a medicinal plant under temperature climate conditions Germany. Acta Hort. 630, 483-489.

MAZZARI A. L. D. A., PRIETO J. M., 2014. Herbal medicines in Brazil: pharmacokinetic profile and potential herb-drug interactions. Front. Pharmacol. 5, doi: 10.3389/fphar.2014.00162.

Mendes M. C. P., Pinheiro R. O., Avelar K. E. S., Teixeira J. L., SA Silve G. M. S., 2008. Pharmacovigilance history in Brazil. Brazil. J. Pharm. 89, 246-251.

Moglia A., LANTERI S., COMINo C., ACQUadro A., DE VOS R., BEEKWILDER J., 2008. Stress-induced biosynthesis of dicaffeoylquinic acids in globe artichoke. J. Agric. Food Chem. 56, 8641-8649.

Morison N., VAissiere B., Martin F., Pecaut P., CAMBON G., 2000. Pollinisation de l'artichaut (Cynara scolymus L.) par l'abeille domestique (Apis mellifera L.) en production de semences hybrides sous abris grillages. Apidologie 31,115-128.

MURAWSKA A., 2016. Zmiany $w$ spożyciu warzyw $w$ Polsce $w$ kontekście zrównoważonej kon sumpcji. Stowarzyszenie Ekonomistów Rolnictwa i Agrobiznesu Rocz. Nauk. 18, 262-267.

NEGRO D., Grieco S., DE LISI A., SARLI G., SONNANTE G., 2011. Chlorogenic acid content variation in artichoke plant parts and physiological stages. Acta Hort. 942, 469-472.

Negro D., Montesano V., GRIECO S., CRUPI P., Sarli G., De Lisi A., Sonnante G. 2012. Polyphenol compounds in artichoke plant tissues and varieties. J. Food Sci. 77, 2, 244-252.
NOLDIN V.F., FILHO V.C., MONACHE F.D., BENASSi J.C., Christmann I.L., PEdRosa R.C., Yunes R. A., 2003. Composição química e atividades biológicas das folhas de Cynara scolymus $L$. (Alcachofra) cultivada no Brasil. Quim. Nova, 26, 331-334.

Pandino G., LOMBardo S., Mauromicale G., WiLLIAMSON G., 2011. Profile of polyphenols and phenolic acids in bracts and receptacles of globe artichoke (Cynara cardunculus var. scolymus) germplasm. J. Food Campos. Anal. $24,148-153$

PARUS. A., 2013. Przeciwutleniajace $i$ farmakologiczne właściwości kwasów fenolowych. Post. Fitoter. 1, 48-53.

Pinelli P., Agostini F., Comino C., Lanteri S., PORTIS E., ROMANI A., 2007. Simultaneous quantification of caffeoyl esters and flavonoids in wild and cultivated cardoon leaves. Food Chem. 105, 1695-1701.

Portis E., MAUROMICAlE G., BARChI L., MAURO R., LANTERI S., 2005. Population structure and genetic variation in autochthonous globe artichoke germplasm from Sicily Island. Plant Sci. 168, 1591-1598.

PYRZYŃSKA E., 2014. Zalecenia żywieniowe $i$ formy ich upowszechniania. Zesz. Nauk. UEK 3, 7586.

Rossoni G., Grande S., Galli C., Visioli F., 2005. Wild artichoke prevents the age-associated loss of vasomotor function. J. Agric. Food Chem., 53, 10291-10296.

Salem M.B., AfFes H., Athmouni K., Ksouda K., DHOUIBI R., SAHNOUN Z., HAMMAMI S., ZEGHAL K.M., 2017. Chemicals compositions, antioxidant and anti-inflammatory activity of Cynara scolymus leaves extracts, and analysis of major bioactive polyphenols by HPLC. Evid.-Based Compl. Alt. Med., doi. org/10.1155/2017/4951937.

SAzATA A., 2005. Dynamika kwitnienia roślin karczocha (Cynara scolymus L.) $w$ zależności od metody uprawy. Acta Agrobot. 59, 463-470.

SAŁATA A., 2007. Yielding and pharmacological value of artichoke herb depending on the cultivation method. Acta Hort. 826, 427-430.

SAEATA A., BUCZKOWSKA H., 2007a. Zależność miedzy norma wysiewu nasion a plonem ziela karczocha (Cynara scolymus L.). Rocz. AR Poznań, Ogrodn. 41, 595-598.

SAEATA A., BUCZKOWSKA H., 2007b. Effect of the method of harvesting on the yield and the content of phenolic compounds in artichoke $(\mathrm{Cy}$ nara scolymus L.) herb. Herba Pol. 53, 110114.

SAlATA A., GRUSZECKI R., 2010. The quantitative analysis of poliphenolic compounds in different part sof the artichoke (Cynara scolymus L.) depending of growth stage of plants. Acta Sci. Pol., Hortorum Cultus 9, 175-181

SAlATA A., NURZYŃSKA-WIERDAK R., STEPANIUK R. ZAWIŚLAK G., 2016. Response of artichoke (Cynara scolymus L.) plants to irrigation and harvest date. Acta Sci. Pol., Hortorum Cultus $15,245-265$.

SAMOCHOWIEC L., 1962. The effect of artichokes (Cynara scolymus L.) and cardoon (Cynara cardunculus L.) on developed atherosclerotic changes in white rats. Fol. Biol. 10, 75-83.

Sato Y., Itagaki S., Kurokawa T., OGURA J., KoBAYASHI M., HIRANO T., SUGAWARA M., ESI$\mathrm{KI} \mathrm{K}$. . 2011. In vitro and in vivo antioxidant properties of chlorogenic acid and caffeic acid. Internat. J. Pharmaceut. 403, 136-138.

ShoAib M., SheHzad A., OMAR M., RAKHA A., RaZA H., Sharif H.R., ShaKeEl A., ANSARI A., NIA- 
ZI S., 2016. Inulin: Properties, health benefits and food applications. Carbohyd. Polym. 147, 444-454.

Speroni E., Cervellati R., Covoni P., Guizzardi S., REnZulli C., Guerra M., 2003. Efficacy of different Cynara scolymus preparation of liver complaints. J. Ethnopharmacol. 86, 203-211.

STROJEWSKA I., 2013. Spożycie owoców, warzyw i ich przetworów oraz soków na świecie, $w$ Unii Europejskiej i w Polsce. Komunikaty. Raporty. Ekspertyzy 562, 5-78.

VAMANU E., VAMANU A., Nita S., Colceriu S., 2011. Antioxidant and antimicrobial activities of ethanol extracts of Cynara scolymus (Cynarae folium, Asteraceae family). Trop. J. Pharm. Res. 10, 777-783.

Velioglu Y.S., MASSA G., GAO L., OOMAH B.D., 1998. Antioxidant activity and total phenolics in selected fruits, vegetables, and grain products. J. Agric. Food Chem. 46, 4113-4117.

WANG M., SimOn J. E., Aviles I. F., He K., ZhenG Q.-Y., TADMOR Y., 2003. Analysis of antioxidative phenolic compounds in artichoke (Cynara scolymus L.). J. Agric. Food Chem. 51, 601608
WINIARSKA S., 2006. Wpływ sposobu zakładania plantacji na wzrost $i$ rozwój karczocha zwyczajnego (Cynara scolymus L.). Acta Agrophysica $8,745-753$.

WÓJCICKI J., 1978. Effect of 1,5-dicaffeoylquinic acid (cinarine) on cholesterol levels in serum and liver of acute ethanol-treated rats. Drug Alkohol Depend. 3, 143-145.

ZAPOLSKA-DOWNAR D., ZAPOLSKI-DOWNAR A., NARUSZEWICZ M., SIENNICKA A., KRASNODEBSKA B., KOŁODZIEJ B., 2002. Protective properties of artichoke (Cynara scolymus) against oxidative stress induced in cultured endothelial cells and monocytes. Life Sci. 71, 2897-2908.

ZHU X., ZHANG H., LO R., 2004. Phenolic compounds from the leaf extract of artichoke $(\mathrm{Cy}$ nara scolymus L.) and their antimicrobial activities. J. Agric. Food Chem. 52, 7272-7278.

ZHU X. F., ZHANG H. X., Lo R., 2005. Antifungal activity of Cynara scolymus L. extracts. Fitoterapia $76,108-111$.

ZielińsKa M. A., BiAeECKA A., PietruszKa B., HAMUŁKA J., 2017. Warzywa i owoce jako źródta wybranych substancji bioaktywnych $i$ ich wpływ na funkcje poznawcze u osób starszych. Postepy Hig. Med. Dosw. 267-280.

KOSMOS Vol. 67, 4, 823-831, 2018

Renata Nurzyńska-Wierdak, ANDRZeJ SAŁata, RAFA£ Stepaniuk

Department of Vegetable Crops and Medicinal Plants, University of Life Sciences in Lublin, 58 Leszczyńskiego Str., 20-068 Lublin,

E-mail: renata.nurzynska@up.lublin.pl

HEALTH-RELATED PROPERTIES OF THE ARTICHOKE (CYNARA SCOLYMUS L., ASTERACEAE)

Summary

Artichoke is grown as a vegetable plant in many Mediterranean countries and in North America, and, as a medicinal plant mainly, in Germany and Poland. The main group of active substances of artichoke are polyphenolic compounds. Scientific findings clearly support healing properties of some artichoke metabolites and the validity of their phytotherapeutic applications. The most important healing properties of the artichoke metabolites are: protection and support of liver functions, antioxidant and antimicrobial activity. This vegetable is also a valuable source of prebiotics, mainly inulin, and has all the advantages of a functional food. Artichoke can therefore be recommended not only as a source of medicinal compounds, but also as a food component that aids the digestive system.

Key words: vegetables, nutritional value, polyphenolic compounds, healing properties 